\title{
PROGRAM PMT DAN GRAFIK PERTUMBUHAN BALITA PADA MASA PANDEMI COVID
}

\author{
Anita Widiastuti, Septerina Purwandani Winarso \\ Poltekkes Kemenkes Semarang \\ Email : anitawidiastuti123@gmail.com
}

\begin{abstract}
The incidence of stunting toddler is a major nutritional problem facing Indonesia. Preventive efforts during a pandemic by providing additional information and food for toddler. The aim is to detect the growth of toodler and to survey the supplementarry feeding program. The data was collected using a web-based information system combined with secondary data from the health center. This type of descriptive analytic research, retrospective cohort time approach to 125 toddlers.

The results showed that there was a decrease in the $Z$ score of body weight / age in children under five for weighing before the program was compared to after the program was running during the Covid pandemic. The $Z$ score height / age increased the percentage for normal height. Meanwhile, there was a decrease in the percentage of very short, short and tall height.

In conclusion, during the Covid pandemic 19 the growth chart for toddler experienced a decrease in terms of body weight per age and experienced stagnation in height growth.
\end{abstract}

Keywords : pandemic; toddler; supplementarry feeding

\begin{abstract}
ABSTRAK
Kejadian balita stunting merupakan masalah gizi utama yang dihadapi Indonesia. Upaya preventif masa pandemic dengan memberikan informasi dan makanan tambahan bagi balita. Tujuan melakukan deteksi pertumbuhan balita dan melakukan survei program PMT. Pengumpulan data dilakukan dengan menggunakan sistem informasi berbasis web dan dipadukan dengan data sekunder dari puskesmas. Jenis penelitian deskriptif analitik, pendekatan waktu kohort retrospektif pada 125 balita.

Hasil penelitian menunjukkan terjadi penurunan $Z$ skore BB/U pada balita untuk penimbangan sebelum ada program dibandingkan setelah program berjalan selama masa pandemic covid. $Z$ skore TB/U terjadi peningkatan prosentase untuk TB Normal. Sementara itu ada penurunan prosentase pada TB sangat pendek, pendek dan tinggi..

Kesimpulan, pada masa pandemic covid 19 grafik pertumbuhan balita mengalami pernurunan dilihat dari berat badan per umur dan mengalami stagnasi pada pertumbuhan tinggi badan.
\end{abstract}

Kata kunci: pandemi; balita; PMT

\section{Pendahuluan}

Pertumbuhan anak perlu dideteksi secara dini melalui intensifikasi pemantauan tumbuh kembang balita. Keluarga diharapkan untuk bisa mendeteksi kondisi kesehatan anak secara mandiri. Selanjutnya deteksi dilakukan di posyandu, dilanjutkan dengan deteksi oleh bidan di desa atau petugas kesehatan lainnya. Bila penambahan tinggi anak lebih rendah dari yang seharusnya, pertumbuhan anak terganggu hal ini mengindikasikan anak mengalami masalah pertumbuhan yang dikenal dengan stunting (Kementrian Kesehatan RI, 2010).

Kejadian balita stunting (pendek) merupakan masalah gizi utama yang 
dihadapi Indonesia. Berdasarkan data Pemantauan Status Gizi (PSG) selama tiga tahun terakhir, pendek memiliki prevalensi tertinggi dibandingkan dengan masalah gizi lainnya seperti gizi kurang, kurus, dan gemuk. Prevalensi balita pendek mengalami peningkatan dari tahun 2016 yaitu $27,5 \%$ menjadi $29,6 \%$ pada tahun 2017 (Kementrian Kesehatan RI, 2018a).

Salah satu fokus pemerintah saat ini adalah pencegahan stunting. Upaya ini bertujuan agar anak-anak Indonesia dapat tumbuh dan berkembang secara optimal dan maksimal, dengan disertai kemampuan emosional, sosial, dan fisik yang siap untuk belajar, serta mampu berinovasi dan berkompetisi di tingkat global (Kementrian Kesehatan RI, 2018b)

Nutrisi yang cukup untuk kebutuhan pertumbuhan bayi dan balita mutlak sangat dibutuhkan. Makanan kaya akan nutrisi diperlukan untuk mencegah gangguan pertumbuhan (Kementrian Kesehatan RI, 2016). Penambahan makanan tambahan sedang di galakkan untuk balita di wilayah desa lokus stunting di Banyumas. Desa Pandak di Kecamatan Baturraden, menjadi salah satu desa pelaksanaan program Pemberian Makanan Tambahan (PMT) untuk desa lokus stunting mulai awal tahun 2020.

Awal tahun 2020 World Health Organization (WHO) telah resmi menyatakan wabah COVID-19 sebagai pandemi global pada tanggal 11 Maret 2020. Menurut data World Health Organization (WHO) per bulan Maret 2020 jumlah kasus COVID-19 yaitu 3.394.963 yang tersebar di 215 negara, salah satunya Indonesia (WHO, 2020). Berdasarkan data Gugus Tugas Percepatan Penanganan COVID-19, Indonesia dengan jumlah kasus konfirmasi positif COVID-19 sebanyak 10.843 yang mana diantaranya sebanyak 1.876 kasus dinyatakan sembuh dan 845 kasus dinyatakan meninggal di awal pandemi 2020, tingkat kematian di Indonesia saat ini yaitu $7,66 \%$ dan Indonesia menjadi salah satu negara dengan resiko tingkat kematian akibat Coronavirus tertinggi di dunia.

Mempertimbangkan penambahan
kasus pemerintah memberlakukan
Pembatasan Sosial Berskala Besar (PSBB)
dan Physical Distancing dalam mencegah
wabah COVID-19. Hal ini berakibat pada
perubahan pelaksanaan Usaha Kesehatan

Berbasis Masyarakat (UKBM) dalam bentuk Posyandu. Kebijakan tersebut membuat balita tidak bisa dipantau pertumbuhan yang secara rutin sudah biasa dilakukan.

Penelitian ini menggunakan sistem informasi sebagai media untuk mendeteksi status gizi balita. Sistem informasi menggunakan sistem pakar berbasis web menghasilkan keluaran berupa program aplikasi atau tool yang dapat digunakan untuk mendeteksi pertumbuhan. Sistem ini dibangun berbasis website agar dapat diakses oleh masyarakat luas dimana pun, sehingga dapat mengurangi resiko kejadian gangguan gizi termasuk stunting dimasa pandemi. Berdasar latar belakang perlu dilakukan penelitian Evaluasi Program PMT Desa Lokus Stunting terhadap Grafik Pertumbuhan Balita pada Masa Pandemi Covid dengan menggunakan system informasi online.

\section{Metode Penelitian}

Penelitian ini menggunakan rancangan deskriptif analitik, pendekatan waktu dalam penelitian adalah retrospektif. Data dihimpun mulai sebelum ada program PMT, dan di analisis dengan data setelah ada PMT. di Dalam penelitian ini populasi adalah balita usia 0-59 bulan sebanyak 219 yang berada di Desa Lokus Stunting (Desa Pandak) Wilayah Baturraden. Jumlah sampel yang digunakan menggunakan rumus Slovin, Sampel yang dibutuhkan 125

Teknik pengambilan sampel dengan Cluster sampling. Balita yang di teliti diambil dari satu desa, kemudian untuk memenuhi perhitungan sampel diambil dari empat posyandu secara proporsional.

\section{Hasil dan Pembahasan}

Hasil survei dari balita yang masuk ke system informasi, bentuk PMT yang diterima antara lain berupa biscuit program nasional, biscuit selain program, susu bubuk, susu cair, bahan makan mentah, dan bahan makanan matang. Dari sekian jenis yang penerimanya paling banyak adalah bentuk biscuit PMT program sebanyak 33,06\%, bahan makanan matang $26,01 \%$ dan susu cair 23,79\%.

Balita penerima PMT program stunting paling banyak adalah kategori 
menerima PMT biskuit karena mengikuti kegiatan penimbangan di posyandu sebanyak $73,63 \%$, balita kurus $5 \%$ serta balita BGM 4,10\%.

PMT yang diterima oleh balita berdasarkan laporan $41,32 \%$ dimakan oleh balita menyisakan sedikit sisa, $38,32 \%$ melaporkan selalu habis dan ada $17,96 \%$ melaporkan sisa masih banyak.

Balita tidak menghabiskan PMT karena alasan tertentu sebanyak $65,10 \%$. Selanjutnya karena alasan tidak mau sebanyak $32,10 \%$

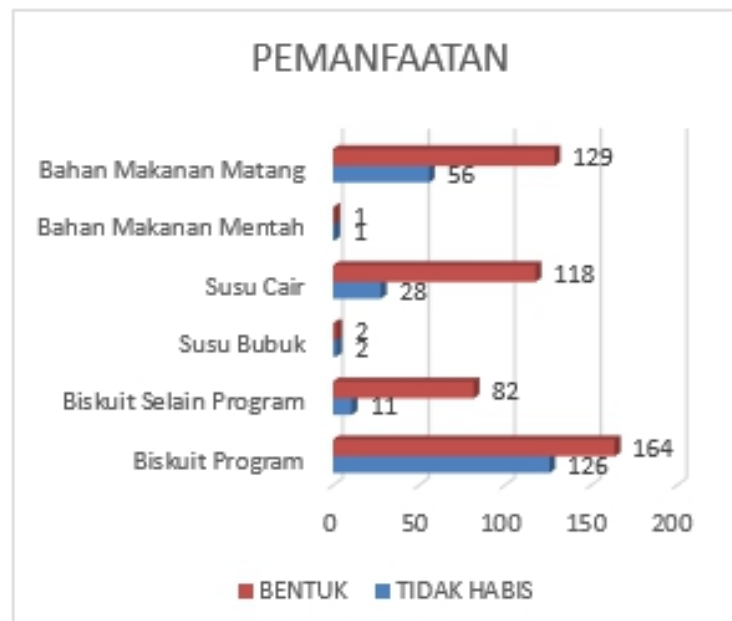

Gambar 1 Survei PMT dan Pemanfaatan Survei selanjutnya adalah mengenai jenis PMT yang paling sering tidak habis tersaji pada gambar 1. Berdasarkan laporan prosentase tertinggi yang tidak dihabiskan adalah bahan makanan mentah dan susu bubuk, disusul berikutnya biscuit program sebanyak 76,83\%. Sedangkan PMT yang sisanya sedikit adalah biscuit selain program $13,41 \%$ serta susu cair sebanyak $23,73 \%$.

PMT belum optimal pemanfaatannya. Salah satu penyebabnya adalah kurangnya perhatian orang tua terhadap pertumbuhan dan perkembangan. Banyak anak ditemukan mengalami keterlambatan pertumbuhan dan perkembangan yang disebabkan oleh kurangnya orang tua yang peduli dalam deteksi dini pertumbuhan dan perkembangan (Utami \& Amalia, 2019).

Gambaran status gizi berdasarkan Z skore BB/U menggunakan standar kementerian kesehatan (Kementrian Kesehatan RI, 2020). Hasil pengukuran sebelum ada program PMT dan setelah ada program PMT terjadi peningkatan prosentase untuk $B B$ sangat kurang, dan $B B$ kurang. Sementara itu ada penurunan prosentase pada BB Normal dan risiko BB Lebih. Data bisa dilihat di table 1.

Status gizi berdasarkan Z Skore TB/U hasil pengukuran sebelum ada program PMT dan setelah ada Program PMT terjadi peningkatan prosentase untuk TB Normal. Sementara itu ada penurunan prosentase pada TB sangat pendek, pendek dan tinggi.

Tabel 1. Gambaran Status Gizi

\begin{tabular}{ccccc}
\hline & \multicolumn{2}{c}{$\begin{array}{c}\text { Sebelum } \\
\text { Program }\end{array}$} & \multicolumn{2}{c}{$\begin{array}{c}\text { Sesudah } \\
\text { Program }\end{array}$} \\
\cline { 2 - 5 } & $\mathrm{n}$ & $\%$ & $\mathrm{n}$ & $\%$ \\
\hline $\begin{array}{c}\text { Status Gizi BB/U } \\
\text { BB Sangat } \\
\text { Kurang }\end{array}$ & 2 & 1.6 & 3 & 2.4 \\
\hline BB Kurang & 14 & 11.2 & 20 & 16 \\
\hline BB Normal & 102 & 81.6 & 98 & 78.4 \\
\hline $\begin{array}{c}\text { Risiko BB } \\
\text { Lebih }\end{array}$ & 7 & 5.6 & 4 & 3.2 \\
\hline $\begin{array}{c}\text { Status Gizi TB/U } \\
\text { Sangat }\end{array}$ & 6 & 4.8 & 3 & 2.4 \\
\hline $\begin{array}{c}\text { Pendek } \\
\text { Pendek }\end{array}$ & 19 & 15.2 & 15 & 12 \\
\hline Normal & 98 & 78.4 & 107 & 85.6 \\
\hline Tinggi & 2 & 1.6 & 0 & 0 \\
\hline
\end{tabular}

Data Z skore selanjutnya diolah untuk mengetahui keadaan sebelum dan sesudah program PMT. Data perubahan grafik pertumbuhan tersaji pada table 2. Penghitungan perubahan grafik dilakukan dengan melihat selisih Z skore pengukuran bulan Agustus dengan Bulan Februari. Hasil negative menunjukkan penurunan, hasil nol berarti tetap dan hasil positif berarti ada peningkatan. Hasil penghitungan Balita yang mengalami penurunan $Z$ skore BB/ $\mathrm{U} 5,2 \%$, balita yang tetap $1,6 \%$ dan yang meningkat $43,2 \%$.

Tabel 2. Gambaran Perubahan Grafik Pertumbuhan

\begin{tabular}{lcc}
\hline Kategori Perubahan & $\mathrm{n}$ & $\%$ \\
\hline $\begin{array}{l}\text { Perubahan Grafik } \\
\text { Pertumbuhan BB }\end{array}$ & & \\
\hline Grafik Turun & 69 & 55,2 \\
\hline Grafik Tetap & 2 & 1,6 \\
\hline Grafik Naik & 54 & 43,2 \\
\hline
\end{tabular}

Perubahan Grafik

Pertumbuhan TB

\begin{tabular}{ccc}
\hline Grafik Turun & 56 & 44,8 \\
\hline Grafik Tetap & 1 & 0,8 \\
\hline Grafik Naik & 68 & 54,4 \\
\hline
\end{tabular}


Gambaran penghitungan pengukuran TB balita yang telah di konversi dalam bentuk $Z$ skore, Balita yang mengalami penurunan $Z$ skore TB/U 44,8 \%, balita yang tetap $1,6 \%$ dan yang meningkat $43,2 \%$. Penghitungan perubahan grafik dilakukan dengan melihat selisih $Z$ skore pengukuran bulan Agustus dengan Bulan Februari. Hasil negative menunjukkan penurunan, hasil nol berarti tetap dan hasil positif berarti ada peningkatan

Tabel 3 menunjukkan resume dari gambaran data BB dan $Z$ skore BB/U yang dilakukan pengukuran sebelum ada program PMT desa lokus stunting dan setelah ada program PMT. Rata rata kenaikan BB dari seluruh responden $0,86 \mathrm{Kg}$ dengan selesih antara BB setelah PMT dengan BB sebelum PMT penurunan terendah $-4,70$ dan kenaikan tertinggi 3,30 selama 6 bulan periode pengukuran. Gambaran rata-rata $Z$ skore BB/U mengalami penurunan sebesar $0,15 \mathrm{SD}$.

Tabel 3 Deskripsi data antropometri

\begin{tabular}{lcccc}
\hline \multicolumn{1}{c}{ Data } & Mean & Min & Maks & SD \\
\hline $\begin{array}{l}\text { Data Berat } \\
\text { Badan }\end{array}$ & & & & \\
\hline $\begin{array}{l}\text { Sebelum ada } \\
\text { program (Kg) }\end{array}$ & 11,08 & 4,00 & 18,4 & \\
\hline $\begin{array}{l}\text { Setelah ada } \\
\text { program (Kg) }\end{array}$ & 11,94 & 5,10 & 19,9 & \\
\hline Selisih BB & 0,86 & $-4,70$ & 3,30 & \\
\hline $\begin{array}{l}\text { Z Skore BB/U } \\
\text { sebelum ada } \\
\text { program (SD) }\end{array}$ & $-0,73$ & $-3,27$ & 3,56 & 1,15 \\
\hline $\begin{array}{l}\text { Z Skore BB/U } \\
\text { setelah ada } \\
\text { program (SD) }\end{array}$ & $-0,88$ & $-3,57$ & 2,83 & 1,11 \\
\hline $\begin{array}{l}\text { Data Tinggi } \\
\text { Badan }\end{array}$ & & & & \\
\hline $\begin{array}{l}\text { Sebelum ada } \\
\text { program } \\
\text { (CM) }\end{array}$ & 86,46 & 50 & 108 & \\
\hline $\begin{array}{l}\text { Setelah ada } \\
\text { program } \\
\text { (CM) }\end{array}$ & 88,34 & 66 & 111 & \\
\hline $\begin{array}{l}\text { Selisih TB } \\
\text { Z Skore TB/U } \\
\text { sebelum ada } \\
\text { program (SD) }\end{array}$ & $-1,01$ & $-4,50$ & 5,37 & 1,29 \\
\hline $\begin{array}{l}\text { Z Skore TB/U } \\
\text { setelah ada } \\
\text { program (SD) }\end{array}$ & $-0,91$ & $-3,80$ & 2,19 & 1,09 \\
\hline & & & & \\
\hline
\end{tabular}

Gambaran data TB dan Z skore TB/U yang dilakukan pengukuran sebelum ada program PMT desa lokus stunting dan setelah ada program PMT. Rata rata kenaikan TB dari seluruh responden 4,88 CM dengan selesih antara TB setelah PMT dengan TB sebelum PMT penurunan terendah 0 dan kenaikan tertinggi $16 \mathrm{CM}$ selama 6 bulan periode pengukuran. Gambaran rata-rata $Z$ skore TB/U mengalami sedikit perubahan sebesar 0,10 SD.

Pemanfaatan PMT merupakan salah satu data yang terekam dalam system informasi penelitian ini. Berdasarkan rekap data yang masuk pemanfaatan PMT belum optimal. PMT yang diberikan banyak yang tidak dimakan oleh balita, seperti PMT tidak di habiskan atau juga dimakan oleh anggota keluarga yang lain. Kondisi ini seperti dilaporkan pada penelitian yang dilakukan oleh (Aryani, 2019) bahwa pelaksanaan program ini belum berjalan dengan optimal seperti tahap pemantauan belum berjalan dengan maksimal dikarenakan terdapat anggota keluarga yang ikut mengkonsumsi, serta pada tahap pencatatan belum dilaksanakan pencatatan harian daya terima terhadap makanan yang diberikan dan cakupan program PMT masih rendah.

Kondisi yang hampir sama juga dilaporkan pada penelitian sebelumnya dimana orang tua balita melaporkan bahwa makanan tambahan yang diberikan untuk balita dimakan oleh kakak balita. Sedangkan anak balitanya hanya memakan sebagian kecil dari porsi yang diberikan (Indriati et al., 2016).

Hasil pemantauan dari bulan Februari sampai dengan Bulan Agustus 2020 menunjukkan informasi bahwa terjadi penambahan jumlah dan prosentase balita yang memiliki kategori berat badan BB Sangat Kurang dan BB Kurang. Disisi lain terjadi penurunan balita yang memiliki kategori BB Normal dan resiko BB lebih. Dan setelah dihitung balita yang $Z$ skore $B B / U$ turun ada $55,2 \%$ dan $Z$ skore yang naik sebanyak $43,2 \%$, sedangkan $1,6 \%$ Z skore tetap.

Perubahan Z skore sebelum dan sesudah pemberian PMT menunjukkan adanya penurunan $Z$ skore BB/U pada balita. Pada survey PMT pemanfaatan PMT oleh masyarakat masih kurang baik. Kebijakan pembatasan social pada pandemic covid 19 diduga turut berperan dalam menurunnya 
suplai nutrisi pada makanan balita. Sehingga secara umum terjadi penurunan status gizi pada balita.

Penyebab utama penurunan status gizi adalah asupan yang kurang. Secara normal tubuh membutuhkan energy, karbohidrat, lemak, protein dalam jumlah seimbang untuk pertumbuhan. Apabila asupan energy kurang dari kebutuhan maka tubuh akan menggunakan cadangan makanan. Bila berlangsung dalam waktu lama maka akan menyebabkan berkurangnya masa tubuh dan terhambatnya pertumbuhan (Hayati, 2014).

Keeratan hubungan antara antara pemenuhan nutrisi dengan status pertumbuhan / gizi anak di bawah usia lima juga jelaskan dalam penelitian (Hartaty, 2017). Pada balita yang pemenuhan nutrisinya sesuai maka pertumbuhannya pun akan sesuai, dan bila nutrisi tidak sesuai maka akan terjadi gangguan pertumbuhan.

Pada masa pandemic pendapatan masyarakat mengalami penurunan. Hal ini diduga menjadi salah satu factor penyebab turunnya grafik pertumbuhan balita meskipun diberi PMT. Seperti penelitian (Nasikhah \& Margawati, 2012) yang menjelaskan bahwa pendapatan perkapita yang rendah merupakan faktor risiko yang berpengaruh terhadap kejadian gangguan status gizi pada balita usia 24 - 36 bulan.

Memperhatikan hasil perbandingan $Z$ skore $B B / U$ yang mengalami penurunan, dengan $Z$ skore $T B / U$ tidak mengalami penurunan. Secara fisiologis berat badan sangat berhubungan dengan kebutuhan energy dan asupan nutrisi pada waktu yang sama. Sehingga bila suplai energy kurang akan mengambil simpanan yang menyebabkan BB berkurang. Sementara tulang ataupun rangka tubuh bukan merupakan cadangan energy. Sehingga tidak langsung tampak/bisa diamati perubahan yang terjadi akibat kekurangan nutrisi.

Deteksi tinggi badan tidak bisa menggambarkan perubahan suplai nutrisi dalam waktu singkat. Hal ini seperti dijelaskan oleh (Hanum et al., 2014) bahwa status gizi anak saat ini untuk Z Skore TB/U merupakan akumulasi dari kebiasaan makan periode waktu sebelumnya, sehingga penurunan asupan makanan saat ini tidak langsung memengaruhi status gizi berdasar tinggi badan.

Pada usia balita tinggi badan tidak mungkin mengalami penurunan, kondisi terburuk adalah sama dengan bulan sebelumnya. Seperti penjelasan (WHO, 2008) bahwa garis pertumbuhan yang datar, juga disebut stagnasi, biasanya mengindikasikan adanya masalah. Jika tinggi badan tetap sama dari waktu ke waktu, artinya anak tidak tumbuh. Sekalipun pada suatu waktu berat badan mengalami penurunan dalam batas wajar, anak tersebut harus terus bertambah tinggi. Masalah ini akan terbukti sebagai garis pertumbuhan datar pada grafik tinggi-umur. Apabila keadaan ini berlanjut tentu akan berdampak tidak baik pada pertumbuhan dan perkembangan Balita.

Pengembangan modifikasi pemantauan pertumbuhan dan perkembangan sangat dibutuhkan. Ini merupakan kebutuhan baru sebagai solusi terpeliharanya kesehatan balita dan terpenuhinya protocol kesehatan di masa pandemic Covid

\section{Keimpulan}

Pada masa pandemic covid 19 grafik pertumbuhan balita mengalami pernurunan dilihat dari berat badan per umur dan mengalami stagnasi pada pertumbuhan tinggi badan. Diharapkan masyarakat lebih optimal dalam memanfaatkan bahan PMT yang diberikan petugas kesehatan, ketika anak tidak mau usahakan untuk memodifikasi jenis PMT yang diterima.

\section{Ucapan Terima Kasih}

Terima kasih peneliti ucapkan kepada Poltekkes Kemenkes Semarang atas kesempatannya sehingga peneliti mendapatkan dana Risbinakes DIPA Poltekkes Kemenkes Semarang, Kepala Puskesmas II Baturraden, Bidan Desa Pandak dan seluruh pihak yang membantu proses penelitian ini yang tidak bisa kami sebutkan satu persatu.

\section{Daftar Pustaka}

Aryani, N. A. (2019). Evaluasi Pelaksanaan Program Pemberian Makanan Tambahan Pemulihan (PMT-P) Untuk Penderita Balita Gizi Buruk (Studi Kasus di Puskesmas Welahan I 
Kabupaten Jepara). UNNES.

Hanum, F., Khomsan, A., \& Heryatno, Y. (2014). Hubungan asupan gizi dan tinggi badan ibu dengan status gizi anak balita. Jurnal Gizi Dan Pangan, 9(1).

Hartaty, N. (2017). HUBUNGAN PEMENUHAN NUTRISI DENGAN PERTUMBUHAN DAN PERKEMBANGAN BALITA. Jurnal Aceh Medika, 1(2), 34-39.

Hayati, N. (2014). Latar Belakang Tidak Meningkatnya Berat Badan Balita Setelah Mendapat Pemberian Makanan Tambahan Pemulihan (Pmt-P) Di Wilayah Kerja Puskesmas Pamulang Tahun 2014.

Indriati, R., Nugraheni, S. A., \& Kartini, A. (2016). Supplementary Feeding Program Evaluation Restoration Malnourished In Children Under Five In The District Wonogiri Seen From Input and Process Aspects. Jurnal Manajemen Kesehatan Indonesia, 3(1).

Kementrian Kesehatan RI. (2010). Peraturan Menteri Kesehatan Republik Indonesia Nomor 155/Menkes/Per/l/2010 tentang Penggunaan Kartu Menuju Sehat (KMS) Bagi Balita. Kementrian Kesehatan RI. https://www.regulasip.id/book/4987/rea d

Kementrian Kesehatan RI. (2016). Peraturan Menteri Kesehatan Republik Indonesia Nomor 51/Menkes/Per/l/2016 tentang Standar Produk Suplementasi Gizi. Kementrian Kesehatan RI. http://hukor.kemkes.go.id/uploads/prod uk_hukum/PMK_No._51_ttg_Standar_ Produk_Suplementasi_Gizi_.pdf
Kementrian Kesehatan RI. (2018a). Infodatin Situasi Balita Pendek. Kementrian Kesehatan http://www.depkes.go.id/resou rces/download/pusdatin/infoda tin/situasi-balita-pendek 2018.pdf.

Kementrian Kesehatan RI. (2018b). Stunting pada anak. Kementrian Kesehatan RI. http://www.depkes.go.id/article/view/18 052800006/ini-penyebab-stunting-pada -anak.html

Kementrian Kesehatan RI. (2020). Peraturan Menteri Kesehatan Republik Indonesia Nomor: 2 tahun 2020 tentang Standar Antropometri Anak. Kementrian Kesehatan RI.

Nasikhah, R., \& Margawati, A. (2012). Faktor risiko kejadian stunting pada balita usia 24-36 bulan di Kecamatan Semarang Timur. Diponegoro University.

Utami, V. N., \& Amalia, R. (2019). PEMBERIAN VIDEO TERHADAP SIKAP IBU BAYI TENTANG DETEKSI DINI PERTUMBUHAN DAN PERKEMBANGAN BAYI. Jurnal Sains Kebidanan, 1(1), 19-24.

WHO. (2008). WHO child growth standards: training course on child growth assessment. Interpreting Growth Indicators. WHO.

WHO. (2020). Coronavirus (COVID-19). WHO. https://covid19.who.int/ 